\title{
Characterization of herbicide-resistant Eucalyptus plants expressing phosphinothricin acetyltransferase gene
}

Esteban González ${ }^{1 *}$, Carla Gugliermoni ${ }^{1}$, Milton Galvão ${ }^{1}$, Maria Fagundes ${ }^{1}$, Maria Ferreira ${ }^{1}$, Guilherme Almeida ${ }^{1}$, Henrique Alves ${ }^{1}$, Jose Gonsalves ${ }^{1}$, Fernando Silva ${ }^{2}$, Sergio Bentivenha ${ }^{2}$, Shinitiro Oda ${ }^{2}$, Eduardo Mello ${ }^{1}$

From IUFRO Tree Biotechnology Conference 2011: From Genomes to Integration and Delivery

Arraial d'Ajuda, Bahia, Brazil. 26 June - 2 July 2011

Herbicide resistant crops are commercially advantageous for efficient field productivity by enabling use of nonselective herbicides for weed management. Herbicide resistant trees could be used to improve productivity and reduce the costs of forest management through to the first and second years post tree establishment. We describe the introduction of the phosphinothricin acetyltransferase (bar) gene, which confers resistance to the herbicide glufosinate, into Eucalyptus pellita (clone EP11) and hybrid Eucalyptus (E. grandis $x$ E. dunni clone SP1383) under the control of a constitutive promoter. The transgenic lines produced showed a copy number ranging from 1 to 3 copies by Southern blot analysis. Herbicide resistance of the transgenic clones was assessed in the greenhouse by application of $200 \mathrm{~g} / \mathrm{L}$ phosphinotricin at the level of $6.0 \mathrm{~L} / \mathrm{ha}$ and $4.0 \mathrm{~L} / \mathrm{ha}$ (commercial rate). The effect of the two herbicide treatments was tested on 4-week and 6-month old plants derived from several transgenic events from the two different Eucalyptus clones. All 4-week old non-transgenic control plants, as well as whole shoots of 6 -month old control plants were killed by the herbicide by fifteen days after application. The same herbicide treatment effectively killed all the weeds in field conditions. All the transgenic plants showed strong resistance to the herbicide in all treatments with no observed negative effects. The use of herbicide resistant trees may provide an additional means for improving the economic efficiency of plantation forest management.

* Correspondence: estebang@suzano.com.br

${ }^{1}$ FuturaGene Brazil Ltda, Brazil

Full list of author information is available at the end of the article
Author details

${ }^{1}$ FuturaGene Brazil Ltda, Brazil. ${ }^{2}$ Suzano Papel e Celulose, Brazil.

Published: 13 September 2011

\section{doi:10.1186/1753-6561-5-S7-P135}

Cite this article as: González et al:: Characterization of herbicide-

resistant Eucalyptus plants expressing phosphinothricin

acetyltransferase gene. BMC Proceedings 2011 5(Suppl 7):P135.
Submit your next manuscript to BioMed Central and take full advantage of:

- Convenient online submission

- Thorough peer review

- No space constraints or color figure charges

- Immediate publication on acceptance

- Inclusion in PubMed, CAS, Scopus and Google Scholar

- Research which is freely available for redistribution

Submit your manuscript at www.biomedcentral.com/submit
Ciomed Central 